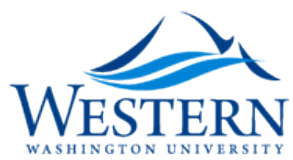

Western Washington University

Western CEDAR

$5-2003$

\title{
Teaching Human Evolution
}

Joan C. Stevenson

Western Washington University, joan.stevenson@wwu.edu

David L. (David Leon) Alles

Follow this and additional works at: https://cedar.wwu.edu/anthropology_facpubs

Cart of the Anthropology Commons

\section{Recommended Citation}

Stevenson, Joan C. and Alles, David L. (David Leon), "Teaching Human Evolution" (2003). Anthropology Faculty and Staff Publications. 4.

https://cedar.wwu.edu/anthropology_facpubs/4

This Article is brought to you for free and open access by the Anthropology at Western CEDAR. It has been accepted for inclusion in Anthropology

Faculty and Staff Publications by an authorized administrator of Western CEDAR. For more information, please contact westerncedar@wwu.edu. 
Teaching Human Evolution

Author(s): David L. Alles and Joan C. Stevenson

Source: The American Biology Teacher, Vol. 65, No. 5 (May, 2003), pp. 333-339

Published by: University of California Press on behalf of the National Association of Biology

Teachers

Stable URL: http://www.jstor.org/stable/4451511

Accessed: 22/10/2014 16:38

Your use of the JSTOR archive indicates your acceptance of the Terms \& Conditions of Use, available at http://www.jstor.org/page/info/about/policies/terms.jsp

JSTOR is a not-for-profit service that helps scholars, researchers, and students discover, use, and build upon a wide range of content in a trusted digital archive. We use information technology and tools to increase productivity and facilitate new forms of scholarship. For more information about JSTOR, please contact support@jstor.org. 


\title{
Teaching HUMAN EVOLUTION
}

\author{
David L. Alles joan C. Stevenson
}

s science educators, we have two goals in writing this paper. The first is to show the importance of teaching human evolution to all students. The second is to provide up-to-date resources for classroom teachers to use in teaching the subject. Secondary biology textbooks suffer from the inherent limitations of mass produced books making it difficult for them to stay current with rapidly changing scientific fields such as paleoanthropology. One of our motives for writing this paper is to compensate for this inherent limitation of textbooks.

The most important resource we provide is a review of current scientific research on human evolution that stresses the broad framework of what is reliably known about our origins. To this we have included a list of recommended books taken from our research that we feel are the most useful and accessible. In addition to text resources, we have added a list of web sites on human evolution that provide an increasingly sophisticated source of information. Together, this material should provide teachers with a

DAVID L. Alles is an Instructor in the Department of Biology and JOAN C. SteVENSON is a Professor in the Department of Anthropology, both at Western Washington University, Bellingham, WA 98225-9160; e-mail: alles@biol.wwu.edu. variety of up-to-date resources for teaching human evolution.

\section{Why Teach Human Evolution?}

Modern science has reached the point where the broad outline of our origin is known. For each of us, this scientific knowledge of human origins and evolution has a special significance, because central to each of our individual views of the world is a concept of who and what we are. The beliefs we hold about ourselves drive our attitudes and our actions and, as such, determine the kind of people we are and ultimately the kind of society we have. In the past we have answered the questions about our origins with the myths and creation stories unique to the culture of our birth. But today we live in a world where scientific answers to these questions are available. All of us can share these answers because they are based on public scientific knowledge instead of private beliefs. It is the knowledge of who and what we are that we can hold in common in our increasingly pluralistic society. This scientific knowledge of human origins need not replace faith in the moral teachings of any belief system. But if self knowledge is the most valuable knowledge we can possess, then what modern science can tell us about who and what we are is the most valuable knowledge we can teach our students. 


\section{A Review of Current Research on Human Evolution}

We have confined our review of human evolution to the period between the late Miocene eight million years ago (m.y.a.) and 100,000 years ago. This period marks the evolutionary transition from our last common ancestor with modern chimpanzees to the first fully modern humans. Because of limited space, and to do proper justice to the subject, we have not included the last hundred thousand years of human evolution and history. Our knowledge of this period is growing daily and is best left as a story in itself.

\section{Setting the Stage}

To fully understand human evolution it should be seen as a recent installment in the much larger story of the evolution of life. Our assumption is that teachers will set this larger stage for the story of human evolution by presenting the history of life on Earth. Human evolution can then be understood as only one chapter in the larger story of vertebrate and mammalian evolution. Having said this, we must confine ourselves in this paper to setting the stage with those events just prior to the evolution of the last common ancestor of chimpanzees and humans.

Ten million years ago Africa had a much wetter climate than today (Coppens, 1999). Tropical rainforests near the equator extended across unbroken lowlands from the Atlantic to the Indian oceans. Starting eight million years ago, tectonic forces began to split east Africa along what we know today as the east African rift valley. Uplift caused by these tectonic forces on the west side of the rift prevented the easterly flow of rain clouds and created a rain shadow over east Africa. The resulting climate change was compounded by a simultaneous global cooling and drying trend. East Africa began to dry out.

These geological events split the common ancestors of modern chimpanzees and ourselves into two geographically separate populations. One population remained in the tropical rain forests of west Africa and gave rise to modern chimpanzees. The other population slowly began to adapt to the increasingly open, dry habitats of east, and perhaps north central, Africa and eventually gave rise to modern humans. The story of human evolution follows the complex history of changing climate followed by evolutionary adaptation and radiation in east African hominins, the group to which all the direct ancestors of modern humans belong.

\section{An Overview}

The following elements provide a framework for the broad patterns of hominin evolution (modified from Foley, 1999).
1. The late Miocene (8-5 m.y.a.) witnessed the diversification of the African apes as the east African climate shifted from tropical rain forest to dryer conditions.

2. Bipedalism developed in late Miocene to early Pliocene hominins (6-4 m.y.a.) on the eastern side of the African continent, possibly in response to more open habitats.

3. An adaptive radiation of African hominins took place between 4 and 1.7 m.y.a., as east Africa again experienced further climate shifts to the dryer conditions of the current Ice Age.

4. The period between 1.7 m.y.a. to the present, which spans over two thirds of the current Ice Age, saw a dramatic increase in the cranial capacity of our ancestors, effectively doubling brain size.

5. This same period includes the explosive geographical expansion and rapid divergence of the genus Homo.

6. This expansion was followed by a subsequent reduction in species richness, first with the extinction of the robust hominins and later of regional species of Homo. These extinctions resulted, finally, in the survival of only one Homo lineage, ourselves.

\section{The Current Cast of Characters}

\section{The Earliest Hominins}

Modern apes and humans differ greatly, but the earliest hominins contrasted in subtle ways from living apes primarily in their increasing reliance on bipedalism. The skeletal indicators of bipedalism include an Sshaped (as opposed to C-shaped) spinal column, a forward placement of the hole at the base of the skull where the spinal column enters (the foramen magnum), and a shortening and broadening of the pelvis to make it "bowl-shaped." These changes were accompanied by shifts in muscle groups, especially the gluteal and hamstring muscles, a lengthening of the lower limbs, particularly the femur in the genus Homo, and changes in the feet to become weight-bearing structures (Poirier \& McKee, 1999).

The earliest possible hominin to date is the newly discovered Sahelanthropus tchadensis from Chad in the Sahel region of sub-Saharan Africa, which has tentatively been dated to between 6 and 7 million years old (Brunet, 2002). The fossils include an almost complete cranium with a mosaic of ape and hominin features but no post-cranial skeletal material that could confirm whether $S$. tchadensis was bipedal. 


\section{Higue il: Uomititi Evolition}

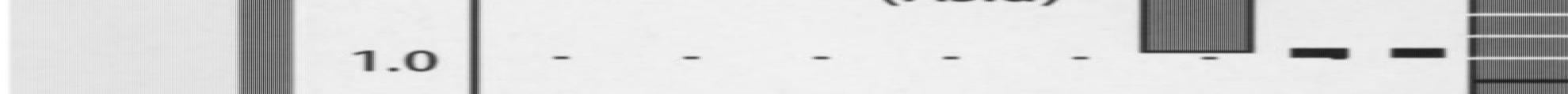

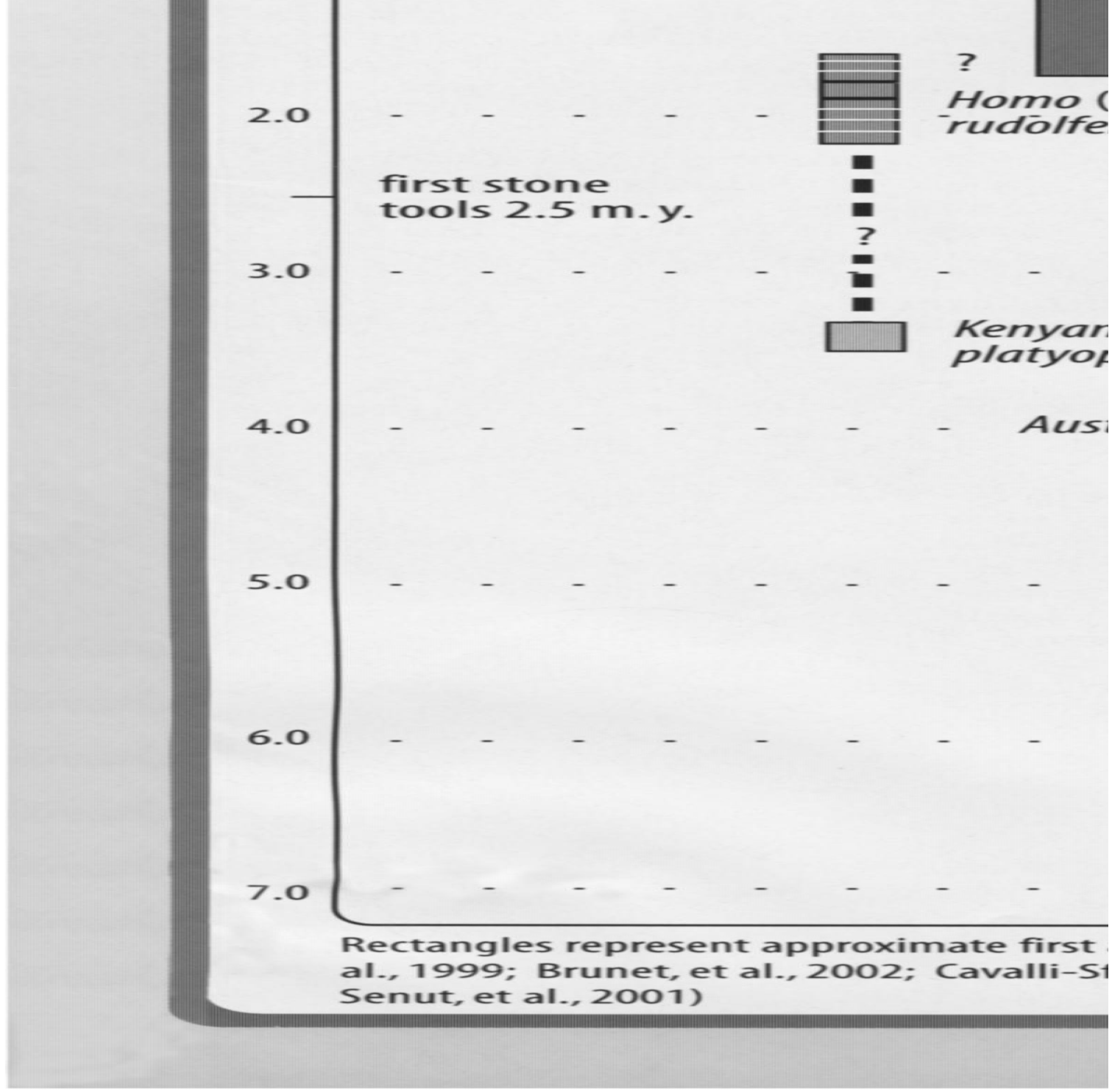


The earliest hominin bipeds may have appeared between 7 to 5 m.y.a. An example of these early bipeds may be the recently discovered fossils of Orrorin tugenensis found in the Tugen Hills of Kenya and dated to 6 m.y.a. (Senut et al., 2001). Thick-enameled, although relatively small, molars and a human-like femur link it with later hominins. It also exhibits muscle attachments on the humerus and curved finger bones that are consistent with arboreal activity linking it to the apes. Based on associated plant and faunal remains, O. tugenensis probably preferred open woodlands near forests.

In addition to $O$. tugenensis, there are 11 specimens representing at least 5 individuals of Ardipithecus ramidus from the Middle Awash area of Ethiopia dating to 5.8-5.2 m.y.a. (Haile-Selassie, 2001). Another 50 partial individuals, representing perhaps a separate subspecies, were recovered at the 4.4 m.y. old site near Aramis, Ethiopia (Klein, 1999). The oldest specimens exhibit derived dental features that are only shared with later hominins (Haile-Selassie, 2001). The fossils from the Aramis site exhibit a forwardly placed foramen magnum and apparently free upper arms, traits consistent with bipedalism (Klein, 1999). However, the association with high altitude, closed canopy woodland habitat, and thin enamel on the molar crowns are characteristics not found in later hominins. This suggests a species at, or close to, the shared ancestor of humans and modern chimpanzees.

\section{Australopiths}

All later hominins, including members of the genus Australopithecus, are characterized by bipedal locomotion, and the numerous species reflect differences in diet and presumed ecological specializations. In general, the older species share more primitive traits with their Miocene forebears. Among these older species are Australopithecus anamensis (4.2-3.9 m.y.a.) from Kenya, and another closely related species, Australopithecus afarensis (3.8-2.9 m.y.a.), from Hadar, Ethiopia and Laetoli, Tanzania (Wood \& Richmond, 2000). Hadar and Laetoli combined provide at least 60 to 100 partial individuals of $A$. afarensis. Adding to these species, a mandible and first upper premolar of Australopithecus bahrelghazali were discovered at Koro Toro, in Chad and dated to 3.5-3.0 m.y.a.. Although initially placed in A. afarensis, these fossils may remain assigned to their own species because of an apparently flatter face evident from the chin.

A. anamensis and A. afarensis exhibit thicker enamel and broader molars indicating a dependence on nuts, grains, or hard fruit. A. anamensis is found in deposits of former riverine woodlands and gallery forests of the Turkana Basin, Kenya. A. afarensis may have occupied more varied habitats from dry bushland to woodlands or riverine forests (Ward et al., 1999). The foramen magnum and tibia of $A$. anamensis are typical of habitual bipeds and the elbow and knee joints may be more humanlike than in $A$. afarensis (Tattersall $\&$ Schwartz, 2000). As in later hominins $A$. anamensis had relatively small upper incisors and less projecting canines. Large, projecting canine teeth are characteristic of our ape ancestors. A. anamensis shares with $A$. afarensis curved fingers and a relatively long radius; both traits would have been useful in the trees. Presumably their bipedalism was intermediate between apes and humans (Stern, 2000).

The better known Australopithecus afarensis includes many partial bones, a skull, and also almost half of an adult female skeleton known as "Lucy" (Wood \& Collard, 1999; Wood \& Richmond, 2000). The skulls, jaws, and teeth are very ape-like except for reduced canines, larger postcanine teeth, and a reduced snout. The body trunks are "inverted funnels," as in the great apes, and the upper limbs are relatively shorter than in apes but longer than in humans. Finger lengths are intermediate but the tips of the fingers are narrow and finger bones are longitudinally curved as in chimpanzees. The feet are also intermediate but include shortened toes and a stout heel characteristic of later hominins. Footprints at Laetoli, possibly made by $A$. afarensis, also support a picture of a habitual biped that stood 1 to 1.5 meters tall and walked fully upright 3.5 m.y.a. (Agnew \& Demas, 1998).

\section{Later Australopiths \& Related Genera}

Specimens of the 3.5-3.3 m.y. old Kenyanthropus platyops, recovered from the Turkana Lake region of Kenya, include a temporal bone, two partial upper jaws, isolated teeth, and most of a cranium (Leakey et al., 2001). The 3.5 m.y. old site includes both former grassland and wooded habitats. Kenyanthropus platyops had a small ear hole, like A. anamensis, and thick enameled cheek teeth and a small brain like $A$. afarensis and $A$. anamensis (Lieberman, 2001). It shares few cranial features with the "robust" hominins (see below), and is distinguished from other australopithecines by derived features of the flatter lower face. The species' unique combination of features, perhaps partly shared with the later Homo rudolfensis, may justify assigning it to the new genus Kenyanthropus.

Several cave sites in South Africa discovered in the 1920s and 1930s revealed the remains of Australopithecus africanus (Wolpoff, 1999). Dating these fossils has traditionally been done by comparing mammal fossils from these sites to fossil mammals from radiometrically dated sites in east African. They suggest that the breccia containing $A$. africanus remains may be 3 to 2.4 m.y. old. Relative to the preceding australop- 
ithecine species the face of $A$. africanus is broader and less projecting. The brain is slightly larger but the body is much the same. Their hands had broader tips presumably associated with larger, sensitive finger pads, a feature found in later species of Homo.

Australopithecus garhi was discovered at Bouri, Ethiopia ( 2.5 m.y. old), and includes the remains of at least 5 hominins found in ancient lake margin sediments (Asfaw et al., 1999; Heinzelin et al., 1999). Its chewing muscles must have been large judging by the teeth and conspicuous postorbital constriction. A. garhi also exhibits a relatively longer femur reminiscent of Homo, but a relatively long forearm is consistent with australopith anatomy.

\section{The "Robust" Hominins}

The term "robust" in paleoanthropology has come to refer to the massive jaws and teeth of a group of later hominins. Robust species exhibit a number of unique and, therefore, derived features including greatly enlarged molars and premolars (Klein, 1999). Some investigators emphasize the unique anatomy of these robust forms by placing them in their own genus, Paranthropus. The earliest member of this group is Paranthropus aethiopicus whose fossils include the famous "Black skull" discovered at West Turkana, Kenya (2.5 m.y. old) and mandibles and teeth recovered from the Omo region of Ethiopia (2.3 m.y. old). P. aethiopicus is similar to $A$. afarensis but differs in its forward placed cheek bones and teeth dimensions that anticipate later robust species.

Remains of Paranthropus boisei, one of the later robust species, have been discovered at many sites throughout east Africa. Paranthropus robustus has been found in many of the cave sites of South Africa. The two species differ only in degree, with P. boisei considered "hyperrobust." They seem to be geographical variants of closely related forms. These later robust species date from 2 to 1.2 m.y.a.. Both exhibit the cranial traits that allowed tremendous force to be applied by the cheek teeth (premolars and molars) during chewing. Their mandibles were large and, like Paranthropus aethiopicus, they had extensive attachments for chewing muscles (e.g., the sagittal crest). The large cheek teeth and skull bones contrast with their stout but small bodies. There are few limb bones for these forms, but in body proportions they were similar to Australopithecus africanus. They are found mainly in deposits of former open, bushy grasslands.

\section{Early Homo}

Homo habilis remains have been found in Tanzania, Ethiopia, and Kenya, from deposits dated to 2.4-1.6 m.y.a. (Wood \& Richmond, 2000). H. habilis, which means "handy man," was originally assumed to be the first stone tool maker as the name implies. There is, however, no unequivocal evidence that $H$. habilis made stone tools. There is also some question as to which genus $H$. habilis should be assigned, either Homo or Australopithecus. In general this species has a slightly larger cranium and narrower teeth. But its long arms and short legs resemble australopiths and, thus, it may not belong in the genus Homo.

In addition, variation in the fossils assigned to this group may be too great to comprise a single species and a subgroup of these specimens have been reassigned to the species Homo rudolfensis. Again it is unclear to which genus this new species will eventually be assigned. Some authorities suggest that it be assigned to the new genus Kenyanthropus, based on similarities to Kenyanthropus platyops. H. rudolfensis remains have been found in Tanzania, Kenya, and Malawi. KNM-ER 1470, the code number of the most famous $H$. rudolfensis cranium, is the best known of these fossils, and, like $H$. habilis, is intermediate in form between australopiths and later humans. It has a large brain and relatively flat face but the enlarged cheek teeth and some facial features are typical of robust hominins. There are no limb bones for this species nor has a specific habitat been identified for either $H$. habilis or $H$. rudolfensis.

The first species to have approximately the same size and limb proportions as modern humans is Homo erectus. The morphology of this species reflects a longrange bipedal adaptation to dryer, open grasslands and variable habitats. Fossils of $H$. erectus have been found at numerous sites in Africa, Asia (Wood \& Richmond, 2000), and the edge of Europe as shown by two discoveries near Dmanisi, Georgia (Gabunia et al., 2000; Vekua el al., 2002). Some authorities recognize a related mostly African (and Dmanisi) species, Homo ergaster, that first appears between 1.9-1.7 m.y.a.. H. ergaster presumably migrated from Africa soon after its origin, spreading mostly to Asia and eventually becoming $\mathrm{H}$. erectus. Asian $H$. erectus may have survived in Indonesia to as recently as 40,000 years ago.

Both $H$. ergaster and $H$. erectus share a larger brain, smaller dentition, a less robust jawbone, a shortened face, and a large browridge (Klein, 1999). Homo erectus differs from $H$. ergaster by possessing a shorter, less domed cranium, thicker cranial bones, sagittal thickening (keel), and more projecting browridges. Some paleoanthropologists do not consider these differences enough to warrant separate species.

\section{Later Homo}

Discoveries in Italy and Spain tentatively assigned to Homo antecessor are dated to 700,000 and 600,000 
years ago, respectively. They provide evidence of an early entry into Europe of people intermediate in form between $H$. erectus and later Homo heidelbergensis. The species Homo heidelbergensis (or Archaic Homo sapiens) describes hominins less than 600,000 years old in Africa, Europe, and Asia (Wood \& Richmond, 2000). This group of fossils differs from Homo sapiens in the heavier build of the body and cranium.

Homo neanderthalensis is a relatively homogeneous group dating between 250,000 and 29,000 years ago. It is represented by many fossils from all over Europe (excluding Scandinavia), and in southwestern and western Asia (Klein, 1999; Hoss, 2000). H. neanderthalensis had large double-arched brow ridges, a projecting face, especially large nose, a weak chin, and brains larger than modern humans. Their bodies were thickset, hands and feet broad, and their limbs exhibited large muscle attachments. The analysis of mitochondrial DNA (mtDNA) recovered from Neanderthal bones and compared to mtDNA of living Homo sapiens supports the conclusion that Homo neanderthalensis was a distinct species from modern humans (Krings et al., 1997; Ovchinnikov et al., 2000).

\section{The Moderns}

At some point between 200,000 and 100,000 years ago, a population of early humans in Africa crossed the morphological threshold to fully modern humans. The timing of this watershed event is supported by a variety of genetic studies (Cavalli-Sforza, 1998). These same studies estimate the number of individuals in this population to be from 20,000 to as few as 2,000 individuals (Harpending, 1998). A population of two thousand individuals is about the size of a large high school in America today.

It challenges the imagination to understand that those two thousand individuals are the ancestors to all six billion plus living human beings. What a stunning moment in time to think of those two thousand individuals poised on the brink of a brave new world. In looking back to this moment we can only wonder what our small band of ancestors might think of our world today.

Because of limited space and the accelerating growth of information about the origin of fully modern humans, we stop our story here at the threshold of our species.

\section{Summary}

New fossil discoveries of our early ancestors are occurring at an increasing rate, each with new names and claims of direct ancestry to modern humans. But even as paleoanthropologists shuffle species names to accommodate these new discoveries, the general outline of human evolution remains sturdy. The astrophysicist James E. Peebles has suggested that rapidly changing sciences, like astronomy and paleoanthropology, are a sign of healthy activity. Shifts in opinion are not a reflection of some inherent weakness, "... rather it shows the subject in a healthy state of chaos around a slowly growing fixed framework. Confusion is a sign that we are doing something right; it is the fertile commotion of a construction site." (Peebles, 2001, p. 55)

It is highly unlikely that the general framework we have portrayed for human evolution will change in the near future, this in spite of the fact that the cast of characters will surely expand with new discoveries, and paleoanthropologists will surely readjust genus and species names to reflect our growing knowledge. And that is good news, for it reflects the healthy chaos of Peeble's busy construction site. By the same token, it is the broad framework of human evolution that every biology student should learn and not a long list of frustrating names. Learning the scientific story of our origin should leave students with a sense of anticipation for further discoveries that will fill in the missing gaps in our knowledge and, in so doing, add further supports to the already sturdy framework of our understanding of human evolution.

\section{Recommended Books}

Cavalli-Sforza, L. L. (2000). Genes, Peoples, and Languages. New York: North Star Press. (One of the most important popular books on human evolutionary genetics brings the story of human evolution up to the present.)

Johanson, D., \& Edgar, B. (1996). From Lucy to Language. New York: Simon \& Schuster. (Although somewhat dated, this book includes David Brill's stunning photographs of the world's most important human fossils.)

Klein, R. G. (1999). The Human Career: Human Biological and Cultural Origins, 2nd Edition. Chicago: University of Chicago Press. (Klein's book, recently updated, is one of the most cited and important books on human evolution. It is somewhat technical but provides a complete and balanced view of human evolution.)

Olson, S. (2002). Mapping Human History: Discovering the Past Through Our Genes. Boston: Houghton Mifflin. (Olson gives an excellent account of recent genetic studies on human evolution.)

Tattersall, I., \& Schwartz, J. (2000). Extinct Humans. New York: Westview Press. (This book gives an overview of the complexity of human evolution and includes magnificent photographs of human fossils by Schwartz.)

Walker, A., \& Shipman, P. (1996). The Wisdom of the Bones. New York: Knopf. (This is one of the best firsthand popular accounts of paleoanthropology by one of its leading practitioners.) 


\section{Recommended Web Sites}

Becoming Human by The Institute for Human Origins, Arizona State University, Tempe, AZ: http://www.becominghuman.org/

Fossil Hominids: The Evidence for Human Evolution in The Talk Origins Archive: http://www.talkorigins.org/faqs/homs/

The Human Origins Program at the Smithsonian Institution: http://www.mnh.si.edu/anthro/humanorigins/

The Hominid Journey by Richard Effland and Ken Costello, Department of Anthropology, Mesa Community College, Mesa, AZ: http://www.mc.maricopa.edu/ reffland/ anthropology/learning/origins/homind_journey/ index.html

\section{References}

$\rightarrow$ Agnew, N., \& Demas, M. (1998). Preserving the Laetoli footprints. Scientific American, 279(March), 44-55.

$\rightarrow$ Asfaw, B., White, T., Lovejoy, O., Latimer, B., Simpson, S. \& Suwa, G. (1999). Australopithecus garhi: A new species of early hominid from Ethiopia. Science, 284, 629-635.

$\rightarrow$ Brunet, M., Guy, F., Pilbeam, D., Mackaye, H. T., Likius, A., Ahounta, D., Beauvilain, A., Blondel, C., Bocherensk, H., Boisserie, J., De Bonis, L., Coppens, Y., Dejax, J., Denys, C., Duringerq, P., Eisenmann, V., Fanone, G., Fronty, P., Geraads, D., Lehmann, T., Lihoreau, F., Louchart, A., Mahamat, A., Merceron, G., Mouchelin, G., Otero, O., Campomanes, P. P., Ponce De Leon, M., Rage, J., Sapanetkk, M., Schusterq, M., Sudrek, J., Tassy, P., Valentin, X., Vignaud, P., Viriot, L., Zazzo, A. \& Zollikofer, C. (2002). A new hominid from the upper Miocene of Chad, Central Africa. Nature, 418(July11), 145-151.

$\rightarrow$ Cavalli-Sforza, L. L. (1998). The DNA revolution in population genetics. Trends in Genetics, 14(February), 60-65.

Coppens, Y. (1999). Introduction. In T.G. Bromage \& Schrenk, F. (Eds.), African Biogeography, Climate Change, $\mathcal{E}$ Human Evolution, (pp. 13-18). New York: Oxford University Press.

Foley, R. (1999). Evolutionary geography of Pliocene African hominids. In T.G. Bromage \& Schrenk, F. (Eds.), African Biogeography, Climate Change, \& Human Evolution, (pp. 328-348). New York: Oxford University Press.

$\rightarrow$ Gabunia, L., Vekua, A., Lordkipanidze, D., Swisher III, C. C., Ferring, R., Justus, A., Nioradze, M., Tvalchrelidze, M., C. Anto 'n, S. C., Bosinski, G., Jo" ris, O., de Lumley, M., Majsuradze, G. \& Mouskhelishvili, A. (2000). Earliest Pleistocene hominid cranial remains from Dmanisi, Republic of Georgia: Taxonomy, geological setting, and age. Science, 288, 1019-1025.

$\rightarrow$ Haile-Selassie, Y. (2001). Late Miocene hominids from the Middle Awash, Ethiopia. Nature, 412, 178-181.

$\rightarrow$ Harpending, H. C., Batzer, M. A., Gurven, M., Jorde, L. B., Rogers, A. R. \& Sherry, S. T. (1998). Genetic traces of ancient demography. Proceedings of the National Academy of Science USA, 95, 1961-1967.

$\rightarrow$ Heinzelin, J., Clark, J. D., White, T., Hart, W., Renne, P., WoldeGabriel, G., Beyene, Y. \& Vrba, E. (1999). Environment and behavior of 2.5-million-year-old Bouri hominids. Science, 284, 625-629.

$\rightarrow$ Hoss, M. (2000). Neanderthal population genetics. Nature, $404,453-454$.

Klein, R. G. (1999). The Human Career: Human Biological and Cultural Origins, 2nd Edition. Chicago: University of Chicago Press.

$\rightarrow$ Krings, M., Stone, A. Schmitz R., Krainitzki, W. H., Stoneking, M. \& Pa"a"bo, S. (1997). Neandertal DNA sequences and the origins of modern humans. Cell, 90(1), 19-30.

$\rightarrow$ Leakey, M. G., Spoor, F., Brown, F. H., Gathogo, P. N., Kiarie, C., Leakey, L. N. \& McDougall, I. (2001). New hominin genus from eastern Africa shows diverse middle Pliocene lineages. Nature, 410, 433-440.

$\rightarrow$ Lieberman, D.E. (2001). Another face in our family tree. Nature, 410, 419-420.

$\rightarrow$ Ovchinnikov. I. V., Gotherstrom, A., Romanova, G., Kharitonov, V. M., Liden, K. \& Goodwin, W. (2000). Molecular analysis of Neanderthal DNA from the northern Caucasus. Nature, 404, 490-493.

Peebles, P. J. (2001). Making sense of modern cosmology. Scientific American, (January), 54-55.

Poirier, F.E., \& McKee, J.K. (1999). Understanding Human Evolution, 4th ed. Upper Saddle River, NJ: Prentice Hall.

Senut, B., Pickford, M., Gommery, D., Mein, P., Cheboi, K. \& Coppen, Y. (2001). First hominid from the Miocene (Lukeino Formation, Kenya). Comptes Rendus de l'Académie des Sciences, Earth and Planetary Sciences, 332, 137-144

$\rightarrow$ Stern, Jr., J.T. (2000). Climbing to the top: a personal memoir of Australopithecus afarensis. Evolutionary Anthropology 9(3), 113-133

Tattersall, I., \& Schwartz, J. (2000). Extinct Humans. New York: Westview Press.

$\rightarrow$ Vekua, A., Lordkipanidze, Rightmire, G. P., Agusti, J., Ferring, R., Maisuradze, G., Mouskhelishvili, A., Nioradze, M., Ponce de Leon, M., Tappen, M., Merab Tvalchrelidze, M. $\&$ Zollikofer, C. (2002). A New Skull of Early Homo from Dmanisi, Georgia. Science, 297(July 5), 85-89.

$\rightarrow$ Ward, C., Leakey, M., \& Walker, A. (1999). The new hominid species Australopithecus anamensis. Evolutionary Anthropology, 7(6), 197-205.

Wolpoff, M. H. (1999). Paleoanthropology, 2nd ed. New York: McGraw Hill

$\rightarrow$ Wood, B., \& Collard, M. (1999). The Human Genus. Science, 284, 65-71.

$\rightarrow$ Wood, B., \& Richmond, B.G. (2000). Human evolution: taxonomy and paleobiology. Journal of Anatomy 196(Pt. 1), 19-60. 